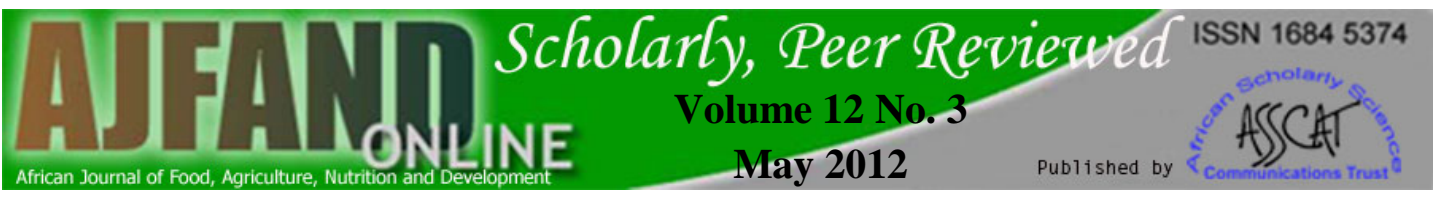

\title{
ASSESSMENT OF HEAVY METALS AND THEIR ESTIMATED DAILY INTAKES FROM TWO COMMONLY CONSUMED FOODS (KULIKULI AND ROBO) FOUND IN NIGERIA
}

\section{Lanre-Iyanda TY ${ }^{1}$ and IM Adekunle $*^{2}$}



TY Lanre-Iyanda

*Corresponding author email: imkunle@yahoo.com

${ }^{1}$ Department of Laboratory Science and Technology, Moshood Abiola Polytechnic, Abeokuta, Nigeria

${ }^{2}$ Department of Environmental Management and Toxicology, University of Agriculture, P.M.B, 2240, Abeokuta, Nigeria 


\section{ABSTRACT}

Most foodstuffs sold in Nigerian outdoor markets are often susceptible to pollution due to poor packaging. As a case study, this work was aimed at the evaluation of heavy metal $(\mathrm{Cd}, \mathrm{Cu}, \mathrm{Zn}, \mathrm{As}, \mathrm{Pb}$ and $\mathrm{Ni})$ content of two widely consumed snack foods in the country, namely melon (robo) and groundnut (kulikuli). The Robo and kulikuli used in this study were purchased from Abeokuta. The products procured directly from the source of preparation served as control samples. All together, a total of two hundred and ninety-four samples were collected for both (kulikuli and robo) from seven different motor parks and forty-two samples of both (50\% for each) formed the control. Samples were ground to powdered form and subjected to acid digestion. The resulting digests were analyzed for the heavy metal concentrations using calibrated atomic absorption spectrophotometer. Field survey was conducted to assess the average consumption of the two food types by an adult of $70 \mathrm{~kg}$ body weight and the daily intake of each was then calculated using standard procedures. Results showed that kulikuli; robo metal concentrations $(\mathrm{mg} / \mathrm{kg})$ were 0.23 to 1.25 ; 0.018 to 0.069 ; 6.73 to 9.23 ; 0.07 to $0.47 ; 13.83$ to 33.13 and 16.15 to 53.91 for As, $\mathrm{Cd}, \mathrm{Cu}, \mathrm{Ni}, \mathrm{Pb}$ and $\mathrm{Zn}$ respectively. Estimated daily dietary intake (mg/kg body weight) from the respective robo and kulikuli, for a $70 \mathrm{~kg}$ body weight, were $5.71 \mathrm{x}$ $10^{-5} ; 8.57 \times 10^{-5}, 9.57 \times 10^{-3} ; 1.1 \times 10^{-2}, 1.57 \times 10^{-4} ; 4.14 \times 10^{-4}, 8.86 \times 10^{-4} ; 1.2$ $\times 10^{-3}, 2.33 \times 10^{-2} ; 3.5 \times 10^{-2}$ and $2.76 \times 10^{-2} ; 6.5 \times 10^{-2}$ for $\mathrm{Cd}, \mathrm{Cu}, \mathrm{Ni}, \mathrm{As}, \mathrm{Pb}$ and $\mathrm{Zn}$, respectively. Only $\mathrm{Pb}$ was above permissible level and based on estimated daily intake, risk factor decreased as $\mathrm{Pb}>\mathrm{As}>\mathrm{Zn}>\mathrm{Cu}>\mathrm{Cd}>\mathrm{Ni}$.

Key words: Foods, metal, contamination, environment, Nigeria 


\section{INTRODUCTION}

Nigeria is popularly referred to as the most populous country in Africa, with over 130 million inhabitants [1]. One of the aftermaths of the increased human population is environmental pollution. It is possible to establish relationships between overpopulation, poverty and urban air pollution. Over population for a country of low gross domestic product spells poverty for the majority of the citizens and poverty prevents proper maintenance of internal combustion, resulting in the use of rickety, old, smoke - belching cars, two-stroke engine motorcycles ("Okada") as means of public transport in the cities. Road traffic is identified to be a major source of air pollution in most Nigerian cities [2]. Air pollution in turn could be a correlate of food contamination. Most food items sold in the Nigerian outdoor markets are not adequately packaged. A great majority of foods such as local snacks, staple foods (cassava foods, rice, beans, grains, oil, fish, vegetable and meat) are displayed close to roadsides.

Although different foodstuffs have been assayed for heavy metal content in Nigeria, there are still a lot more that have not been assessed. Examples include some snack foods such as melon and groundnut cakes locally called robo for melon product and kulikuli for groundnut formulation. Robo is commonly consumed in the southwest region of the country while kulikuli is widely consumed across the nation. These snack foods are packed in containers such as basin, bowls, without any covering and displayed by the roadside. Alternatively, food vendors hawk them at motor parks as fast snack food, for commuters.

Food safety is an important aspect of a nation's economic stability and due to previous reports on the degree of pollution of some other food items $[3,4,5,6]$, this study was aimed at assessing some heavy metal (As, $\mathrm{Cd}, \mathrm{Cu}, \mathrm{Ni}, \mathrm{Pb}$ and $\mathrm{Zn}$ ) levels of the two common food snacks; kulikuli and robo, using the products sold in Abeokuta, south-west Nigeria as a case study. In addition, estimated dietary intakes of the metals were also calculated.

Heavy metals, if present even in very low concentrations in foods, have the capability to cause human health problems. Information about the dietary intake of such metals is important to assess risks to consumers. Dietary intake could account for some fractions of the toxic metals found in the blood and urine of many Nigerians [7, 8, 9, 10]. Arsenic toxicity depends on the valence state, physical and chemical properties of the compound in which it occurs. Trivalent arsenic interacts with sulfhydryl group of proteins and enzymes. Pentavalent arsenic substitutes phosphate groups in oxidative phosphorylation. Arsenic, because of chemical similarities to phosphorus (P), is able to replace $\mathrm{P}$ in many plant cell reactions and shows much harmful toxicity to plants and animals. On absorption of the metal, it initially accumulates in the liver, kidney, lung, spleen, aorta and skin [11].

General symptoms of chronic arsenic exposure include weakness, general debility and lassitude, loss of appetite and energy, hair loss, hoarseness of the voice, weight loss and mental abnormalities. Related health problems include skin and vascular 
disorders (acrocyanosis, angina pectoris, hypertension, myocardial infarction, mesenteric thrombosis, systemic occlusive arterial disease, bronchiectasis and recurrent bronchi-pneumonia), neuropathy, gastroenteritis, hepatoxicity and hematological abnormalities such as anemia and leucopenia [11].

Cadmium has no known biological functions. It interferes with some essential function of $\mathrm{Zn}$, thereby inhibiting enzyme reactions and nutrient utilization. It catalyzes oxidation reactions, generating free-radical tissue damage [12]. Zinc, an essential trace element is more toxic in salt form than in elemental form. Its ingestion causes gastrointestinal toxicity, pulmonary toxicity, nephrotoxicity and neurotoxicity $[13,14,15]$.

Copper is an essential trace metal, vitally important for both physical and mental development in human, usually found in many food types particularly vegetarian foods such as nuts, seeds and grains. It is important for energy production in cells and is required for women's fertility in relation to estrogen metabolism amongst others. However, $\mathrm{Cu}$ accumulates easily in the body, hence, chronic low level intakes of heavy metals have damaging effects on human beings and other animals, since there is no good mechanism for their elimination. Conditions associated with increased copper body burden are arthritis, fatigue, insomnia, scoliosis, osteoporosis, heart disease, cancer, migraine, heart seizures, gum diseases, skin and hair problems. Reported also are mental and emotional disorders such as depression mood swings, fears, anxiety, panic attacks, violence and memory loss [14, 15].

Nickel is also an essential trace element whose role in the body is yet fully known. It is contained in many body tissues. Ordinarily, nickel is not known to be toxic to the body as the body does not readily absorb it [16]. However, nickel can combine with carbon monoxide (CO) to form a complex, nickel tetracarbonyl (Ni (CO) ${ }_{4}$ ), which is extremely poisonous, even more than $\mathrm{CO}$, which is one of its precursor. Elevated dietary intake of the metal is associated with increased thyroid problems, cancer and heart disease [17].

Lead serves no useful purpose in the body and its toxicity affects virtually every organ in the human body. Its ability to mimic or inhibit calcium affects the actions of calcium-dependent or related processes. Pb also interacts with proteins such as sufhydryl, amine, phosphate and carboxyl groups. The toxic metal primarily affects the peripheral and central nervous systems, renal functions, blood cells, metabolism of vitamins D. It is associated with hypertension, reproductive toxicity, developmental effects and neurological disorders, some of which may be irreversible $[16,18]$.

\section{MATERIALS AND METHODS}

\section{Study area}

Abeokuta is the capital of Ogun State in the southwestern region of the country, inhabited primarily by the Yoruba ethnic group. The motor parks, like in any other Nigerian city are located randomly near major outdoor markets. Stationary shops are 
constructed within the parks and mobile traders and hawkers display their goods for commuters and drivers to buy.

\section{Ethics}

Permissions were obtained from the scientific committees of the Moshood Abiola Polytechnic and University of Agriculture, Abeokuta and the research was conducted following ethical procedures.

\section{Sample collection}

A challenge to the collection of kulikuli and robo samples was that most of the vendors were mobile, therefore not restricted to a particular location, moving from one end of a park to the other. Effort was therefore made to reduce the incidence of procuring products from the same vendor. It is a common practice for a vendor to sell either kulikuli or robo in multiples to customers. The quantity of each product in a pack varies with price. In line with this, at a particular motor pack, three packs of a given product were randomly purchased per week for seven weeks from different vendors. In the laboratory, one sample was then removed from each product pack per week and stored for metal analysis.

Hence, twenty-one samples of groundnut cake (kulikuli) were collected from each of the seven motor parks in the city namely Asero, Adatan, Sapon, Ita-oshin, Lafenwa, Itoku and Kuto. Similarly, twenty-one samples of melon cake (robo) were procured from each of the stations. In addition, twenty-one samples of each food product were collected from the production centers, to serve as controls. All together, a total of two hundred and ninety four (21 x7 x2) samples were collected for both kulikuli and robo from the seven different motor parks and forty-two (21 x2) samples of both food types served as controls. Samples were stored in transparent polythene bags, segregated according to food type and transported to the laboratory for metal analysis.

\section{Analytical precision and quality assurance}

Samples were cautiously collected to avoid contamination. All the glassware used were washed clean with distilled water after soaking for $24 \mathrm{~h}$ in $1 \% \mathrm{HNO}_{3}$, and analytical grade reagents purchased from Aldrich Chemical Company Limited, England were used. Reagent blank determinations were used to correct errors. Multiplicity of samples $(n=21)$ for each determination ensured reproducibility of data.

\section{Metal determination}

The samples were oven dried at $105^{\circ} \mathrm{C}$ to constant weight for 90 minutes, cooled to room temperature of $28 \pm 1^{\circ} \mathrm{C}$ and ground to fine powder in a porcelain mortar and exactly $1 \mathrm{~g}$ of the ground sample was quantitatively transferred into a well-glazed porcelain crucible, placed in a muffle furnace and ashed at $450^{\circ} \mathrm{C}$ for 12 hours. The resultant ash was cooled to room temperature and digested to a clear solution with 5 $\mathrm{ml}$ of $5 \mathrm{M} \mathrm{HNO}_{3}$. The residue was then filtered into a calibrated $50 \mathrm{ml}$ volumetric flask using Whatman No. 41 filter paper, and the solution was made up to mark with deionised water. The total concentrations of the metals in the digests were determined by aspirating the solution into Buck Model 210A atomic absorption 
spectrophotometer after the necessary standardization procedures and the respective spectral lines (nm) were 213.9, 283.3, 324.7, 228.8, 232.0 and 193.7 for $\mathrm{Zn}, \mathrm{Pb}, \mathrm{Cu}$, $\mathrm{Cd}, \mathrm{Ni}$ and As respectively from hollow cathode lamps.

\section{Estimation of daily dietary intake}

Field survey for estimation of average consumption of the two food types

Individual or household consumption data for various food types such as vegetables, cereals, pulses, fruits, fish, meat, eggs, milk, dairy products, fats, oils, legumes, nuts, grains, cakes and staple foods are not available in Nigeria in comparison to the developed countries [19]. Field survey was conducted, using the procedures described in Adekunle et al. [6]. The weight of products consumed by adult on daily basis was evaluated and the value obtained was $100 \mathrm{~g}$ on the average. The daily intake of each was calculated by multiplying the respective concentration in each food (melon or groundnut cake) by the food weight (100 g) and dividing the product by the body weight of a typical adult of $70 \mathrm{~kg}$ body weight.

\section{Statistical analysis}

Results were generally expressed as mean \pm standard deviation. In order to ascertain if there was significant variations at $\mathrm{p} \leq 0.05$ for a particular metal level in each product in relation to the different motor parks, data were subjected to Analysis of Variance (ANOVA) and Duncan Multiple Range Test (DMRT) to separate the means.

\section{RESULTS}

\section{Trace metal level and their daily human intake}

Results showed that kulikuli; robo metal concentrations (mg/kg) were 0.23 to 1.25 ; 0.018 to 0.069 ; 6.73 to $9.23 ; 0.07$ to $0.47 ; 13.83$ to 33.13 and 16.15 to 53.91 for As, $\mathrm{Cd}, \mathrm{Cu}, \mathrm{Ni}, \mathrm{Pb}$ and $\mathrm{Zn}$ respectively and the summary of the pooled data are also presented ((Tables 1-3). The relative abundance of the metals decreased in the order $\mathrm{Zn}>\mathrm{Pb}>\mathrm{Cu}>\mathrm{As}>\mathrm{Ni}>\mathrm{Cd}$ for both groundnut and melon cakes. Metal concentrations in all the samples from the motor parks were higher than those found in the control samples and the level of a particular metal was higher in groundnut cake than in melon cake food. In comparison with the control, the primary contaminant in the cakes, obtained from all the study sites (motor parks and production centres), was $\mathrm{Pb}$.

The overall contributions of the snack foods to consumer metal daily intake (Fig.1) were $5.71 \times 10^{-5} ; 8.57 \times 10^{-5} \mathrm{mg}$ of Cd, $9.57 \times 10^{-3} ; 1.1 \times 10^{-2} \mathrm{mg}$ of $\mathrm{Cu}, 1.57 \times 10^{-}$ $4,4.14 \times 10^{-4} \mathrm{mg}$ of Ni, $8.86 \times 10^{-4} ; 1.2 \times 10^{-3} \mathrm{mg}$ of As, $2.33 \times 10^{-2} ; 3.5 \times 10^{-2} \mathrm{mg}$ of $\mathrm{Pb}$ and $2.76 \times 10^{-2} ; 6.5 \times 10^{-2} \mathrm{mg}$ of $\mathrm{Zn}$ per $\mathrm{kg}$ body weight respectively. Only exposure to $\mathrm{Pb}$ and $\mathrm{As}$ exceeded the established maximum acceptable daily dietary intake levels in $\mathrm{mg} / \mathrm{kg}$ body weight [13, 17, 20, 21]. Results indicated that risk of toxic metal intake from both food types above the acceptable daily dose decreased in the order $\mathrm{Pb}>\mathrm{As}>\mathrm{Zn}>\mathrm{Cu}>\mathrm{Cd}>\mathrm{Ni}$. 

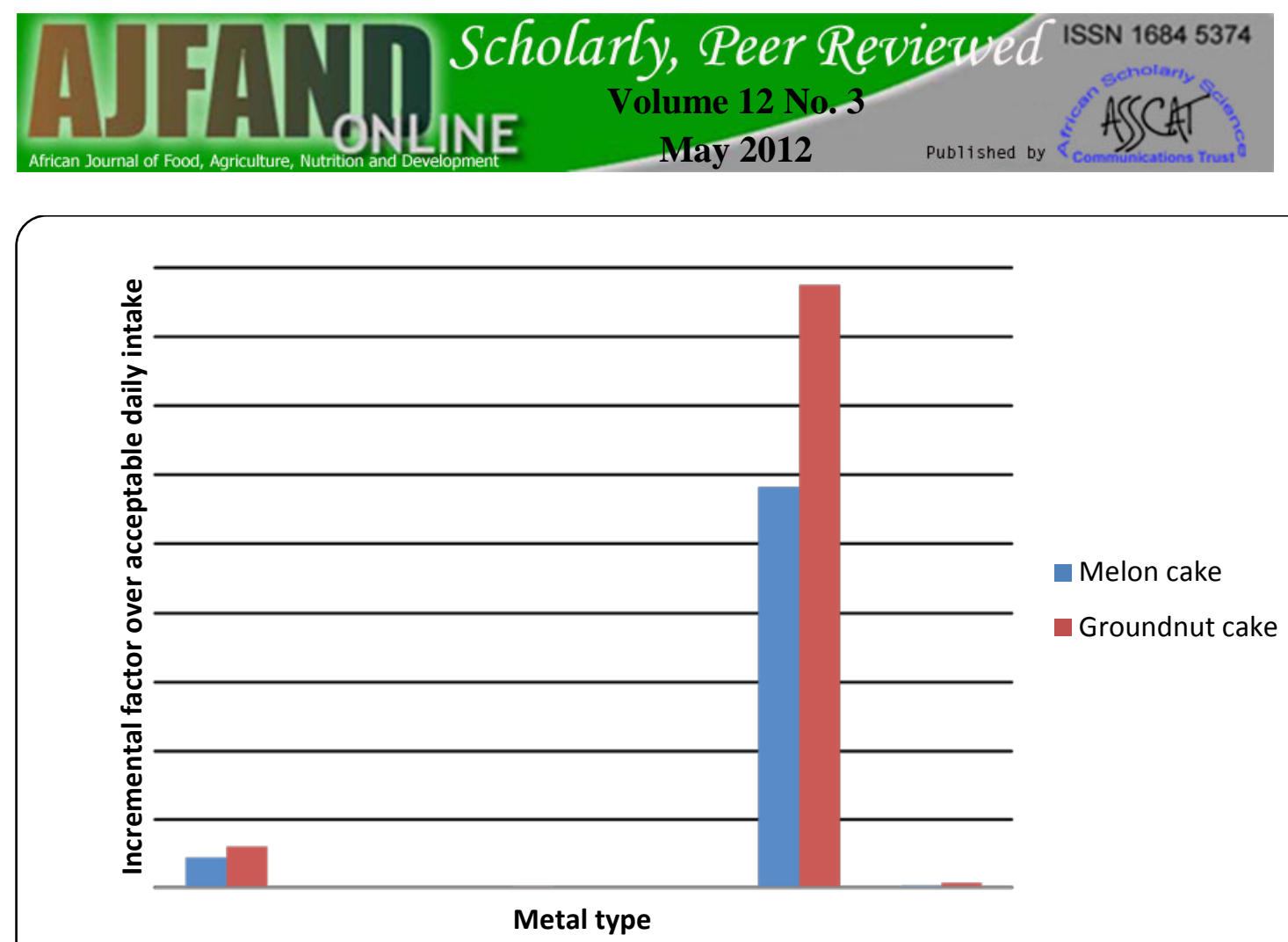

Figure1: Incremental factor of estimated daily intake of metals from melon and groundnut cakes over the acceptable daily intake

\section{DISCUSSION}

Excess metal concentrations in all the samples from the motor parks, in comparison to those found in the control samples, was attributed to atmospheric contamination. Elevated metal in groundnut cake relative to melon cake was probably due to the fact that melon cake was prepared from melon seeds, which are usually above the soil surface, unlike groundnut in which the reverse is the case [22]. Predominance of $\mathrm{Pb}$ over the other metals in all the samples, suggests that $\mathrm{Pb}$ is still the primary pollutant in the Nigerian environment, which is attributed to vehicular emissions and related automobile activities such as auto mobile repairs, battery waste disposal on land amongst others. Leaded gasoline is still utilized in Nigeria with estimated annual release of gaseous $\mathrm{Pb}$ in urban areas put at 2800 metric tonnes. The other metals ( $\mathrm{Zn}$, $\mathrm{Cd}, \mathrm{Cu}$, and $\mathrm{Ni}$ ) are often used as minor additives to gasoline and different autolubricants [ 23, 24, 25,26].

Other sources of metals in the food products include; indiscriminate combustion of solid wastes and cigarette smokes released by smoking drivers and commuter could also be a contributory factor to metal in the foods [7, 27, 28], which could contribute to atmospheric pollution, contaminated process water and the soil - root transfer mechanisms in the soils, where the parent plant materials were grown via fertilizers (inorganic and manure fertilizer) in addition to sprays and dusts used as insecticides and pesticides for crop protection during cultivation [22]. A strong relationship 
between soil heavy metals and farm produce was reported [6, 29] in Nigeria, suggesting that soil pollution is a contributory factor to food metal contamination in Nigeria.

Metals have been reported by Nigerian authors in a variety of foodstuffs in the country. These include vegetables, dry fish, smoked fish, meat preparations, spices, cocoa and cocoa products among many $[3,5,6,29,30]$. Trace metal in foods such as cereals, wheat, maize, rice, biscuit, legumes and beans have also been reported in different parts of the world [19, 31]. However, with the advent of the use of lead free gasoline in the developed countries, $\mathrm{Pb}$ levels in foods are very much below the threshold of $0.2 \mathrm{mg} / \mathrm{kg}$ [20].

When compared with the results (1.11 $\times 10^{-2}$ to $2.02 \times 10^{-2} \mathrm{mg} / \mathrm{kg}$ body weight) obtained on $\mathrm{Pb}$ in green leafy vegetables, commonly consumed in Nigeria, the value obtained in this study for $\mathrm{Pb}\left(2.33 \times 10^{-2} ; 3.5 \times 10^{-2} \mathrm{mg} / \mathrm{kg}\right.$ body weight $)$ is higher, suggesting that the risk of metal (such as $\mathrm{Pb}$ ) entry into the human system may be higher via consumption of these exposed food snacks relative to vegetable consumption [6]. Such commonly consumed contaminated food snacks could play a significant role in elevated blood Pb levels reported in some Nigerians [7, 8, 9].

This phenomenon is not peculiar to Nigeria alone. Santos et al. [32] reported daily intake of eight elements via foodstuffs as $3.4 \times 10^{-4} \mathrm{mg}$ of Uranium (U) $1.8 \times 10^{-3} \mathrm{mg}$ of Cd, $2.8 \times 10^{-3} \mathrm{mg}$ of $\mathrm{Pb}, 2.3 \times 10^{-2} \mathrm{mg}$ of $\mathrm{Cr}, 8.9 \times 10^{-2} \mathrm{mg}$ of Ni, $1.12 \mathrm{mg}$ of $\mathrm{Cu}$, $2.5 \mathrm{mg}$ of $\mathrm{Mn}, 3.5 \mathrm{mg}$ of $\mathrm{Al}$ and $4.8 \mathrm{mg}$ of $\mathrm{Zn}$ from meat, cow milk, flours, wheat and manioc consumed by the adult inhabitants of Rio de Janeiro. Similarly, for adult male population of Catalonia [19], metal intakes (mg/kg body weight) from vegetables, pulses, cereals, fruits, fish foods, meat, eggs, dairy products, milk, fats and oils were in the range of $4.86 \times 10^{-3}$ to 2.90 of As, $1.43 \times 10^{-2}$ to $4.72 \times 10^{-2}$ of $\mathrm{Cd}$, and $2.57 \times$ $10^{-3}$ to $7.06 \times 10^{-2}$.

\section{CONCLUSION}

Trace metals ( $\mathrm{Pb}, \mathrm{Cd}, \mathrm{Ni}, \mathrm{Cu}, \mathrm{Zn}$ and $\mathrm{As}$ ) were detected in the foodstuffs (kulikuli and robo). Lead appeared to be the predominant metal contaminant and was the only element that exceeded the recommended safe level of dietary exposure. The risk factors of dietary exposures to the metals for the consumers decreased in the order $\mathrm{Pb}$ $>\mathrm{As}>\mathrm{Zn}>\mathrm{Cu}>\mathrm{Cd}>\mathrm{Ni}$.

\section{RECOMMENDATION}

It is recommended that regular monitoring of these food categories be conducted, to avoid metal build up in the body, whose detrimental impact becomes apparent only after several years of exposure. 


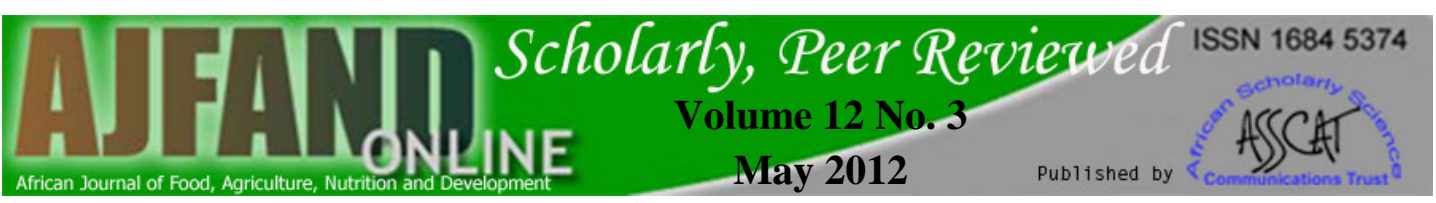

Table 1: Trace metal concentrations $(\mathrm{mg} / \mathrm{kg})$ in melon cakes sold at different motor parks in Abeokuta

\begin{tabular}{|c|c|c|c|c|c|c|}
\hline \multirow[t]{2}{*}{ Location } & \multicolumn{6}{|c|}{ Trace metals } \\
\hline & $\mathrm{Cd}$ & $\mathrm{Cu}$ & $\mathrm{Pb}$ & $\mathrm{Zn}$ & $\mathrm{Ni}$ & As \\
\hline Asero $(n=21)$ & $\begin{array}{c}0.048 \\
+0.001^{\mathrm{a}}\end{array}$ & $6.79 \pm 0.25^{b}$ & $19.88 \pm 0.71^{b}$ & $16.15 \pm 1.90^{\mathrm{C}}$ & $0.12 \pm 0.02^{b}$ & $0.68 \pm 0.11^{b}$ \\
\hline Adatan $(n=21)$ & $\begin{array}{c}0.049 \\
+0.008^{\text {a }}\end{array}$ & $7.07 \pm 0.13^{b}$ & $18.30 \pm 3.11^{\mathrm{b}}$ & $21.78 \pm 1.53$ & $0.12 \pm 0.02^{b}$ & $0.84 \pm 0.11^{\mathrm{b}}$ \\
\hline Sapon $(n=21)$ & $\begin{array}{c}0.052 \\
\pm 0.005^{\mathrm{a}}\end{array}$ & $6.77 \pm 0.13^{b}$ & $13.83 \pm 0.88^{\mathrm{d}}$ & $18.43 \pm 0.73^{\mathrm{b}}$ & $0.08 \pm 0.01^{\mathrm{c}}$ & $0.38 \pm 0.17^{c}$ \\
\hline $\begin{array}{l}\text { Ita }- \text { oshin }(n= \\
21)\end{array}$ & $\begin{array}{c}0.018 \\
\pm 0.009^{\mathrm{b}}\end{array}$ & $8.03 \pm 0.26^{\mathrm{a}}$ & $14.88 \pm 2.23^{c}$ & $19.95 \pm 0.70^{\mathrm{a}}$ & $0.15 \pm 0.03^{\mathrm{a}}$ & $0.23 \pm 0.03^{c}$ \\
\hline $\begin{array}{l}\text { Lafenwa }(\mathrm{n}= \\
21)\end{array}$ & $\begin{array}{c}0.057 \\
+0.006^{\mathrm{a}}\end{array}$ & $7.93 \pm 0.26^{\mathrm{a}}$ & $17.90 \pm 0.92^{\mathrm{b}}$ & $19.63 \pm .2 .93^{\mathrm{b}}$ & $0.15^{\mathrm{a}} \pm 0.03^{\mathrm{a}}$ & $1.18 \pm 0.06^{\mathrm{a}}$ \\
\hline Itoku $(\mathrm{n}=21)$ & $\begin{array}{c}0.028 \\
+0.010^{\mathrm{b}}\end{array}$ & $6.73 \pm 0.13^{\mathrm{b}}$ & $19.60 \pm 2.48^{\mathrm{a}}$ & $20.73 \pm 0.67^{\text {a }}$ & $0.07 \pm 0.02^{\mathrm{c}}$ & $0.89 \pm 0.04^{b}$ \\
\hline Kuto $(\mathrm{n}=21)$ & $\begin{array}{c}0.045 \\
\pm 0.008^{\text {a }}\end{array}$ & $7.83 \pm 0.29^{\mathrm{a}}$ & $15.75 \pm .0 .57^{\mathrm{c}}$ & $18.55 \pm 0.15^{\mathrm{b}}$ & $0.13 \pm 0.02^{\mathrm{a}}$ & $0.79 \pm 0.11^{b}$ \\
\hline Control $(n=21)$ & $\begin{array}{c}0.005 \\
+0.001^{\mathrm{b}}\end{array}$ & $2.53 \pm 0.25^{c}$ & $10.23 \pm 0.35^{\mathrm{a}}$ & $16.70 \pm 1.25^{c}$ & $0.04 \pm 0.01^{\mathrm{d}}$ & ND \\
\hline
\end{tabular}

Sample population is denoted by $\mathrm{n}$, values in the same column with different superscripts are significantly different from each other $(\mathrm{P} \leq 0.05)$. ND $=$ not detected. Permissible limits for $\mathrm{Cd}$ in all foods $=0.05 \mathrm{mg} / \mathrm{kg}$, permissible limits for $\mathrm{Cu}$ in all foods $=10 \mathrm{mg} / \mathrm{kg}$, permissible limits for $\mathrm{Pb}$ in nonleafy foods such as cereals, nuts, legumes $=0.2 \mathrm{mg} / \mathrm{kg}$, permissible limits for $\mathrm{Zn}$ in grains $=50 \mathrm{mg} / \mathrm{kg}$., permissible limits for $\mathrm{Ni}=0.5 \mathrm{mg} / \mathrm{kg}$. 


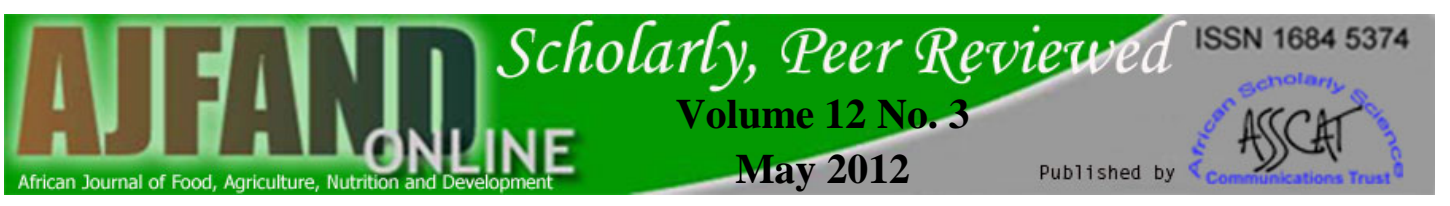

Table 2: Trace metal concentrations $\left(\mathrm{mgKg}^{-1}\right)$ in groundnut cakes (Kulikuli) sold at different motor parks in Abeokuta

\begin{tabular}{|c|c|c|c|c|c|c|}
\hline \multirow[t]{2}{*}{ Location } & \multicolumn{6}{|c|}{ Trace metal } \\
\hline & Cd & $\mathrm{Cu}$ & $\mathrm{Pb}$ & $\mathrm{Zn}$ & $\mathrm{Ni}$ & As \\
\hline \multirow[t]{2}{*}{ Asero $(n=21)$} & 0.052 & $7.29 \pm 0.23^{c}$ & $25.79 \pm 0.25^{c}$ & $43.99 \pm 0.44^{c}$ & $0.40 \pm 0.03^{\mathrm{a}}$ & $1.00 \pm 0.25^{b}$ \\
\hline & $\pm 0.006^{\mathrm{a}}$ & & & & & \\
\hline \multirow[t]{2}{*}{ Adatan $(n=21)$} & 0.057 & $8.23 \pm 0.17^{b}$ & $40.63 \pm 7.25^{a}$ & $53.91 \pm 3.33^{\mathrm{a}}$ & $0.17 \pm 0.04^{b}$ & $1.25^{\mathrm{a}} \pm 0.50^{\mathrm{a}}$ \\
\hline & $\pm 0.001^{\mathrm{a}}$ & & & & & \\
\hline \multirow[t]{2}{*}{ Sapon $(n=21)$} & 0.058 & $7.10 \pm 0.08^{c}$ & $17.10 \pm 1.84$ & $43.07 \pm 3.58^{d}$ & $0.13 \pm 0.04$ & $0.62 \pm 0.13^{c}$ \\
\hline & $\pm 0.002^{\mathrm{a}}$ & & & & & \\
\hline Ita - oshin $(\mathrm{n}=$ & 0.069 & $8.97 \pm 0.49^{a}$ & $15.03 \pm 3.08$ & $42.87 \pm 0.44^{d}$ & 0.33 & $0.25 \pm 0.02^{d}$ \\
\hline 21) & $\pm 0.008^{\mathrm{a}}$ & & & & $\pm 0.04^{\mathrm{ab}}$ & \\
\hline \multirow[t]{2}{*}{ Lafenwa $(n=21)$} & 0.062 & 9.23 & $33.13 \pm 1.41^{b}$ & $43.15 \pm 0.70^{d}$ & $0.46 \pm 0.03^{a}$ & $1.50 \pm 0.01^{a}$ \\
\hline & $\pm 0.005^{a}$ & $\pm 0.21^{\mathrm{ab}}$ & & & & \\
\hline \multirow[t]{2}{*}{ Itoku $(n=21)$} & 0.059 & 8.13 & $27.03 \pm 2.09$ & $48.27 \pm 0.81^{b}$ & 0.33 & $0.98 \pm 0.15^{b}$ \\
\hline & $\pm 0.008^{\mathrm{a}}$ & $\pm 0.13 b^{c}$ & & & $\pm 0.02^{\mathrm{ab}}$ & \\
\hline \multirow[t]{2}{*}{ Kuto $(n=21)$} & 0.067 & $9.20 \pm 0.08^{a}$ & $26.68 \pm 0.74^{c}$ & $44.67 \pm 1.77^{c}$ & $0.47 \pm 0.02^{\mathrm{a}}$ & $1.13^{b} \pm 0.38^{b}$ \\
\hline & $\pm 0.002^{\mathrm{a}}$ & & & & & \\
\hline \multirow[t]{2}{*}{ Control $(n=21)$} & 0.057 & $3.07 \pm 0.17^{d}$ & $10.52 \pm 1.28^{\mathrm{e}}$ & $43.92 \pm 1.58^{c}$ & $0.06 \pm 0.01^{b}$ & ND \\
\hline & $\pm 0.002^{\mathrm{a}}$ & & & & & \\
\hline
\end{tabular}

Sample population is denoted by $\mathrm{n}$, values in the same column with different superscripts are significantly different from each other $(\mathrm{P} \leq 0.05)$. ND $=$ not detected Permissible limits for Cd in all foods $=0.05 \mathrm{mg} / \mathrm{kg}$, permissible limits for $\mathrm{Cu}$ in all foods $=10 \mathrm{mg} / \mathrm{kg}$, permissible limits for $\mathrm{Pb}$ in nonleafy foods such as cereals, nuts, legumes $=0.2 \mathrm{mg} / \mathrm{kg}$, permissible limits for $\mathrm{Zn}$ in grains $=50 \mathrm{mg} / \mathrm{kg}$., permissible limits for $\mathrm{Ni}=0.5 \mathrm{mg} / \mathrm{kg}$. 


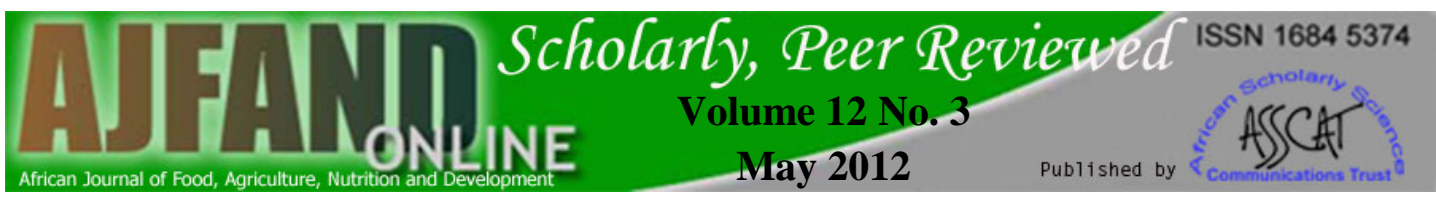

Table 3: Summary of pooled data from the seven stations, for metal concentrations in kulikuli and robo found in Abeokuta, Nigeria

\begin{tabular}{|c|c|c|}
\hline Parameter & $\begin{array}{c}\text { Melon cake }(\mathrm{mg} / \mathrm{kg}) \\
(\mathrm{n}=147)\end{array}$ & $\begin{array}{c}\text { Groundnut cake (m } \\
(n=147)\end{array}$ \\
\hline \multicolumn{3}{|l|}{ Metal } \\
\hline \multicolumn{3}{|c|}{ Concentration in food $(\mathrm{mg} / \mathrm{Kg})$} \\
\hline As & $\begin{array}{c}0.62 \pm 0.36 \\
(0.23-1.18)\end{array}$ & $\begin{array}{c}0.84 \pm 0.48 \\
(0.25-1.25)\end{array}$ \\
\hline $\mathrm{Cd}$ & $\begin{array}{c}0.04 \pm 0.01 \\
(0.018-0.057)\end{array}$ & $\begin{array}{c}0.06 \pm 0.01 \\
(0.052-0.069)\end{array}$ \\
\hline $\mathrm{Cu}$ & $\begin{array}{c}6.7 \pm 1.7 \\
(6.73-8.03)\end{array}$ & $\begin{array}{c}7.7 \pm 1.9 \\
(7.10-9.23)\end{array}$ \\
\hline $\mathrm{Ni}$ & $\begin{array}{c}0.11 \pm 0.04 \\
(0.07-0.13)\end{array}$ & $\begin{array}{c}0.29 \pm 0.15 \\
(0.13-0.47)\end{array}$ \\
\hline $\mathrm{Pb}$ & $\begin{array}{c}16.3 \pm 3.1 \\
(13.83-19.88)\end{array}$ & $\begin{array}{c}24.5 \pm 9.3 \\
(15.03-33.13)\end{array}$ \\
\hline $\mathrm{Zn}$ & $\begin{array}{c}19.3 \pm 1.7 \\
(16.15-21.78)\end{array}$ & $\begin{array}{c}45.5 \pm 3.8 \\
(42.87-53.91)\end{array}$ \\
\hline \multicolumn{2}{|c|}{ Dietary intake $(\mathrm{mg} / \mathrm{kg} / \mathrm{bw})$} & $1.20 \times 10^{-3}$ \\
\hline $\mathrm{Cd}$ & $5.71 \times 10-^{5}$ & $8.57 \times 10^{-5}$ \\
\hline $\mathrm{Cu}$ & $9.57 \times 10^{-3}$ & $1.10 \times 10^{-2}$ \\
\hline $\mathrm{Ni}$ & $1.57 \times 10^{-4}$ & $4.14 \times 10^{-4}$ \\
\hline $\mathrm{Pb}$ & $2.33 \times 10^{-2}$ & $3.50 \times 10^{-2}$ \\
\hline $\mathrm{Zn}$ & $2.76 \times 10^{-3}$ & $6.50 \times 10^{-2}$ \\
\hline
\end{tabular}

Values in parenthesis $=$ range for trace metal level for metal concentration, acceptable daily intake (ADI) established by WHO (1982) for a $70 \mathrm{~kg}$ person: $\mathrm{Cd}=0.06, \mathrm{Cu}=0.05-0.5, \mathrm{~Pb}=0.003-$ $0.004, \mathrm{Zn}=0.3-1.0, \mathrm{Ni}=1.3$ and $\mathrm{As}=0.002$, unit in $\mathrm{mg} / \mathrm{kg} /$ body weight, $\mathrm{n}=$ total number of test samples excluding controls 


\section{REFERENCES}

1. World Bank. Nigeria-Data and statistics. On line at http://web.worldbank.org/WBSITE/EXTERNAL/COUNTRIES/AFRICAEXT /NIGERIAEXTN/0,,menuPK:368922 pagePK:141132 piPK:141109 theSite PK:368896,00.html, (2009), Accessed 4 July, 2011.

2. Taiwo $\mathbf{O}$ case of Lagos-Air quality improvement project. On line at: http://www.cleanairnet.org/ssa/1414/articles-69320_Taiwo.pdf, (2005), Accessed 31 May, 2010.

3. Onianwa PC, Adetola C, Iwegbue CM and O Tella Trace heavy metal composition of some Nigerian beverages and food drinks. Food Chemistry 1999; 66: 275 -279.

4. Okoye COB Lead and other metals in dried fish from Nigerian markets. Bulletin of Environmental Contamination and Toxicology 1994; 52: 825 -823.

5. Adekunle IM and MF Akinyemi Lead levels of certain consumer products in Nigeria: a case study of smoked fish foods from Abeokuta. Food and Chemical Toxicology 2004; 42: 1463 - 1468.

6. Adekunle IM, Olorundare $\mathbf{O}$ and $\mathbf{C}$ Nwange Assessments of lead levels and dietary intakes from green leafy vegetables of southwest, Nigeria. Nutrition \& Food Science, 2009; 39 (4): 413-422, DOI: 10.1108/0034665091097628.

7. Babalola OO, Adekunle IM, Okonji RE, Ejim-Eze EE and O Terebo Selected heavy metals in blood of male Nigerian smokers. Pakistan Journal of Biological Sciences 2007; 10 (20): 3730 - 3733.

8. Ademuyiwa O, Arowolo TA, Ojo DA, Odukoya OO, Yusuf AA and TF Akinhanmi Lead levels in the blood and urine of some residents of Abeokuta, Nigeria. Trace Elements and Electrolytes, 2003; 19 (2): 63 - 69.

9. Adekunle IM, Ogundele JA, Oguntoke $O$ and OA Akinloye Assessment of blood and urine lead levels of some pregnant women residing in Lagos, Nigeria. Environmental Monitoring and Assessment, DOI: 10.1007/s10661009-1247-4.

10. Ayodele JT and AS Bayero Arsenic in the blood and urine of some inhabitants of Gombe State, Nigeria. ASSET Series B 2003; 1(2): 107 - 117.

11. USEPA. United States Environmental Protection Agency. Toxicological profile for arsenic. Agency for Toxic Substances and Disease Registry Office of Health and Environmental Assessment, Environmental Criteria and Assessment Office, Research Triangle Park, NC. EPA 600/8-32-021F, 1984. 
12. WHO. World Health Organization. Cadmium Environmental Health Criteria, Vol. 134, Geneva 1992.

13. CAC. Codex Alimentarius Commission. Evaluation of certain food additives and contaminants. FAO/WHO, Codex stand. 230 - 2001, Rev, 1-2003. Rome (2003).

14. Conti FC and F Carcea Trace metals in soft and durum wheat from Italy. Food and Contaminants 2000; 17: 45-53.

15. Schuhmacher $\mathbf{M}$, Domingo JL, Llobet $\mathbf{J}$ and $\mathbf{J}$ Corbella Dietary intake of copper, chromium and zinc in Terragona Province, Spain. Sci. Total Environ 1993; 132: $3-1$.

16. Mottet NK Disease; Heavy metal pathology Mc Graw-Hill, Inc., New York; 1980: 357.

17. WHO. World Health Organization. Toxicological evaluation of certain food additives and food contaminants WHO Food series 17, Geneva, 1982.

18. WHO. World Health Organization. Environmental Health Criteria, Vol. 165, Geneva: 1995.

19. Llobet JM, Falco G, Casas G, Teixido A and JL Domingo Concentrations of arsenic, cadmium, mercury and lead in common foods and estimated daily intake by children, adolescents, adults and seniors of Catalonia, Spain. Spain. J. Agric. Food Chem 2003; 51: 838 - 842.

20. EC. European Communities. Amending regulation, setting maximum levels of certain contaminants in foodstuffs. Official Journal of European Communities 2002. L37, 4-6.

21. WHO. World Health Organization. Toxicological evaluation of certain food additives and food contaminants WHO Food series 18, Geneva 1983.

22. Alloway BJ Heavy Metals in Soils. Blackie Academic Press, New York: 1995.

23. Ndiokwere CL A study of heavy metal pollution from motor vehicle emission and its effect on road soils, vegetation and crops in Nigeria. Environmental Pollution (Series B) 1984; 7: 35 - 42 .

24. Sridhar MKC Lead exposure in urban centers: case study from Ibadan, Nigeria Epidemiology 1984; 10 ( 22): 227.

25. Onianwa PC, Jaiyeola $\mathbf{O M}$ and RN Egekenze heavy metals contamination of topsoil in the vicinities of auto-repair workshops, gas stations and motorparks in a Nigeria city Toxicol., and Environmental Chemistry 2001; 84 (1-4): 33-39. 
26. Adekunle IM, Arowolo TA, Ndahi NP and B Babajide Chemical characteristics of humic acids in relation to lead, copper and cadmium levels in contaminated soils of southwest Nigeria. Annals of Environmental Science 2007; 1: $23-34$.

27. Nnorom IC, Osibanjo O and EG Oji-Nnorom Cadmium determination in cigarettes in Nigeria. African Journal of Biotechnology 2005; 4(10): 11281132.

28. Adekunle AA, Adekunle IM and NP Ndahi Solid Waste Management by combustion: Implication on metals in the environment In: Proceedings of the WEDC $29^{\text {th }}$ International Conference "Towards the millennium development Goals”, Abuja, Nigeria, 2003; 3-5.

29. Yusuf AA, Arowolo TA and O Bamgbose Cadmium, copper and nickel levels in vegetable from industrial and residential areas of Lagos city, Nigeria. Food and Chemical Toxicology 2003; 41: 375 - 378.

30. Nnorom IC, Osibanjo $\mathbf{O}$ and $\mathbf{O}$ Ogugua Trace heavy metal levels of some bouillon cubes and food condiments readily consumed in Nigeria. Pakistan Journal of Nutrition 2007; 6 (2): 122 - 127.

31. Jorherm $\mathbf{L}$ and $\mathbf{B}$ Sundestroem Amending regulation, setting maximum levels of certain contaminants in foodstuffs. Journal of Food Composition and Analysis 1993; 6: 223 - 241.

32. Santos EE, Lauria Dc and CL Porto daSilveira Assessment of daily intake of trace elements due to consumption of foodstuffs by adult inhabitants of Rio de Janeiro city. Sci. Total Environ 2004; 327 (1-3): 69-79. 